\title{
Evaluation of Waste-to-Energy Potential of Domestic Solid Wastes in Benin Metropolis, Nigeria
}

\section{*119BINOMWANHIA, DI; OBANOR, AI; OLISA, YP; AKHATOR, PE}

\author{
${ }^{1}$ Mechanical Engineering Department, Faculty of Engineering \\ University of Benin, Benin City, Nigeria \\ 2 and ${ }^{4}$ Mechanical Engineering Department, University of Benin, Benin City, Nigeria \\ ${ }^{3}$ Mechanical Engineering Department, Niger Delta University, Amassoma, Nigeria \\ Corresponding author: Email: digbinomwanhia@uniben.edu
}

\begin{abstract}
The solid waste crisis in the fast urbanizing Benin metropolis is the result of inability of the local government authorities to effectively handle the huge amount of waste generated daily. A large percentage of the solid waste in the metropolis ends up on illegal waste dumpsites. The aim of this paper was to investigate the waste-to-energy potentials of domestic solid wastes in Benin metropolis, Nigeria using a three-phase study plan - study of current waste management activities, characterization of domestic solid waste and determination of the waste-to-energy potentials of domestic solid waste. The results obtained reveal that about $13.18 \%$ of combustible solid waste is generated in Benin metropolis with average calorific value (CV) of $20,198.89 \mathrm{~kJ} / \mathrm{kg}$ producing an energy value of $36.95 \mathrm{MW} / \mathrm{day}$. (C) JASEM

http://dx.doi.org/10.4314/jasem.v20i4.23
\end{abstract}

Key Words: Characterisation, Waste-to-Energy Potentials, Domestic Solid Waste, Benin Metropolis

The fourth schedule of the constitution of the Federal Republic of Nigeria rest the mandate for refuse (solid waste) disposal on the local government authorities (FRN, 1999). In recent years, the fast urbanizing Benin metropolis has been faced with solid waste management problems because the local government authorities have not been able to handle the waste generated in the metropolis. Solid wastes generated from household and commercial activities are dumped indiscriminately in the metropolis. A large percentage of the solid waste generated in the metropolis is dumped on illegal waste dumps; when solid waste accumulates, households and businesses pile them up in the median of major roads and set the waste on open fire without pollution control. The magnitude of the solid waste problem in the metropolis is hard to comprehend. The sizes of the public waste bins provided by waste management agents are not large enough and the amount of solid waste that accumulates in a matter of hours is more than the local government authorities waste disposal agents could handle in a day.

A preliminary study on solid waste management in Benin Metropolis (Igbinomwanhia and Ohwovoriole, 2012) showed that solid waste management practice in Benin metropolis is inefficient. Solid waste management is given very low priority in the budget due to limited finances. As a result very limited funds are provided to the solid waste management sector by the governments, and the levels of services required for protection of public health and the environment are not attained. The disposal service charges collected by the local government waste disposal agents are too little to make any significant impact on solid waste management. However, users' ability to pay for the services is also limited by their income and their willingness to pay for the services which are irregular and ineffective is not high either. The waste collected by the local government authorities waste disposal agents are transported to the approved dump sites which are former mining sites where laterite was mined for building and road construction in the metropolis. The approved solid waste dumps are located on the sides of highways while some illegal dumpsites are located at the fringe of metropolis. The production and disposal of large amounts of waste in dumpsites is a loss of the earth's resources. Dumping waste in approved or unapproved dumpsites certainly is inefficient materials management as it does not bring financial returns at the end point of the waste. It needs to be remembered, however, that although the earth is an open system regarding energy, it is essentially a closed system for materials (McDougall et al, 2001).

In the past, environmental aesthetics and health safety were the major concerns in waste management. However the society demands more than these today, solid waste management must also be sustainable. Sustainable solid waste management is defined as waste management which meets the needs of the present without compromising the ability of future generations to meet their own waste management needs (WCED, 1987). Sustainable solid waste management is regarded as the progressive and balanced achievement of sustained economic acceptability, improved social equity and environmental quality (Moldan, 1997). If a sustainable solid waste management scheme must be 
actualised, a waste management system which ensures financial returns at the end point of the waste must be included in the waste management mix designed. Incineration with energy recovery is a sustainable waste management system that ensures financial returns at the end point of the waste.

The work reported in this paper was therefore aimed at investigating commercial waste-to-energy potentials of domestic solid waste in Benin metropolis, Nigeria.

\section{MATERIALS AND METHODS}

A three phase study plan - a study of current waste management activities in Benin metropolis, characterisation of domestic (household) solid waste and evaluation of the potentials of domestic solid for waste-to-energy in Benin metropolis was applied.

In the first phase, a study of government agencies reports/records, private agency reports, personal communication with private and government waste management agencies and a preliminary field work in Benin metropolis was carried out.

This was followed by characterisation of domestic solid waste using site-specific study (U.S. Environmental Protection Agency, 2006), (U.S. Environmental Protection Agency, 2015) which involved sampling, sorting, and weighing the individual components of the waste stream sample. Structured questionnaires were also applied to collect primary information such as size of households, income, educational level etc. from households.

A stratified sampling method (European Commission, 2004) was applied to select a representative sample. The total population in Benin metropolis is made up of about $1,085,676$ persons (Nigeria Population Commission, 2007), The population was broken down into household units. The average household size in Nigeria is 4.3 (National Bureau of Statistics, 2012). Based on Nigeria Population Commission (NPC) submission the total households are about 252483. A representative sample size was calculated using a confidence level of $95 \%$ and confidence interval (margin of error) of $4 \%$. The minimum number of households in any solid waste characterisation is 50 per 500 households and a maximum of 250 households in the sampling area (EPA Ireland, 1996). A total of 250 households was therefore selected as sampling units for the survey. Each selected sampling unit was visited several times. In the first visit, contact was made and participation consent requested. Upon approval, a second visit was made to distribute questionnaires and moderate size bags for storing their solid waste over the following seven days. The next visits were made at regular intervals to collect the solid waste generated over seven days, retrieve the questionnaires and conduct interviews at each household selected for the study. The waste was carefully separated into the component and measured. Samples of the waste were also collected for the third phase of the work. The survey was carried out for six weeks and Table 1 shows the results from the survey.

In the third phase of the work the calorific values (CV) of samples of the waste collected during the characterisation process in Benin metropolis was determined using oxygen bomb calorimeter in the laboratory and the $\mathrm{CV}$ was applied to determine the obtainable heat energy value in Benin metropolis.

\section{RESULTS AND DISCUSSION}

This work revealed that the current waste management practice in the metropolis is not sustainable because there is no financial return at the end point of the waste. The waste disposal trucks collect waste from household and transport them to the dumpsites. At the dumpsites the trucks drive in through the access roads and dump their waste. Other vehicles that deliver waste to the site simply dump their waste indiscriminately by the road sides. Since there are no means for containment, solid waste often spreads into the road, blocking traffic and causing social disorder. The workers at the dumpsites use shovel to manually push the waste from the road and try to spread them as much as their strength can go. Thereafter, open air incineration without pollution control is carried out on the waste for volume reduction.

In the characterisation process a total $5373.61 \mathrm{~kg}$ of domestic solid waste was measured within the period of characterisation study. Based on this figure a daily generation rate of $0.425 \mathrm{~kg}$ per person per day (ppd.) was realised as shown in Table 1 . The result indicated that about $13.18 \%$ of combustible solid waste is generated from domestic source of solid waste in the metropolis.

The results from the determination of $\mathrm{CV}$ of the combustible solid waste components generated in Benin metropolis showed the values presented in Table 2. These values indicated that the average calorific value of the combustible waste components analysed is $20,198.89 \mathrm{~kJ} / \mathrm{kg}$. This is higher than the $7,000 \mathrm{~kJ} / \mathrm{kg}$ (Rand et al, 2000) minimum average calorific value of waste required for setting up an 
incineration plant with energy recovery. Therefore the obtainable heat energy value from combustible solid waste in Benin metropolis is $1,228 \mathrm{GJ} /$ day for domestic source. The analysis carried out for the application of the obtainable energy for steam generation at an output temperature of $250^{\circ} \mathrm{C}$ and a pressure of 5 bar indicated that steam power of $36.95 \mathrm{MW} /$ day can be realised. This may be applied for process heating. In addition the analysis carried out for the application of the obtainable energy for steam generation at an output temperature of $400^{\circ} \mathrm{C}$ and a pressure of $20 \mathrm{bar}$ indicated that steam power of $31.29 \mathrm{MW} /$ day can be realised when the steam generated is applied for driving a steam turbine as shown in Table 3. This may also be applied for electrical power production systems.

Table 1: The average component of household solid waste generated per person per day in Benin metropolis.

\begin{tabular}{lcc}
\hline \multicolumn{1}{c}{ Component } & $\begin{array}{c}\text { Component } \\
\text { (kg/person/day) }\end{array}$ & \%Component \\
\hline Biodegradable waste & 0.334 & 78.59 \\
Conbustible waste & 0.056 & 13.18 \\
Non Combustible Waste & 0.035 & 8.23 \\
Total & 0.425 & 100.00 \\
\hline
\end{tabular}

Table 2: The calorific value of combustible waste components in Benin metropolis

\begin{tabular}{lc}
\hline Waste component & $\begin{array}{c}\text { Calorific value } \\
\text { of waste }(\mathrm{kJ} / \mathrm{kg})\end{array}$ \\
\hline Wood & 16,580 \\
Leather & 19,050 \\
Rubber & 22,197 \\
Plastic LDPE & 33,712 \\
Paper & 14,085 \\
Carton & 14,353 \\
Textile & 17,476 \\
Palm kernel fibre & 25,771 \\
Palm kernel shell & 18,566 \\
PEFB & 17,854
\end{tabular}

LDPE Low Density Polyethylene, PEFB - Palm empty fruit bunch

Table 3: The operating parameters of the waste to energy plant

\begin{tabular}{lccc}
\hline \multicolumn{1}{c}{ Operation } & $\begin{array}{c}\text { Output } \\
\text { Temperature } \\
\left({ }^{0} \mathrm{C}\right)\end{array}$ & $\begin{array}{c}\text { Output Pressure } \\
\text { (bars) }\end{array}$ & $\begin{array}{c}\text { Obtainable Steam } \\
\text { Power (MW/day) }\end{array}$ \\
\hline Process Heating & 250 & 5 & 36.95 \\
Electrical Power Production & 400 & 20 & 31.29 (turbine power) \\
\hline
\end{tabular}

Conclusion: The study revealed that about $13.18 \%$ of combustible solid waste is generated in Benin metropolis. The study also showed that the average $\mathrm{CV}$ of combustible domestic solid waste generated in Benin metropolis is $20,198.89 \mathrm{~kJ} / \mathrm{kg}$. This is higher than the 7,000kJ/kg (Rand et al, 2000) minimum average calorific value of waste required for setting up an incineration plant with energy recovery. Therefore the obtainable heat energy value from combustible domestic solid waste generated from Benin metropolis is $1.228 \mathrm{GJ} /$ day.

Steam power of $36.95 \mathrm{MW} /$ day at an output temperature of $250^{\circ} \mathrm{C}$ and a pressure of 5 bar can be realised from domestic solid waste in Benin metropolis. In addition the analysis carried out also indicated that if steam is generated at a temperature of $400^{\circ} \mathrm{C}$ and a pressure of $20 \mathrm{bar}$, a steam power of $31.29 \mathrm{MW} /$ day can be achieved.

Recommendations: There is poor solid waste storage, collection and transportation system in Benin metropolis. Therefore, there is need to formulate a policy that ensures sorting of solid waste at source and enlightening citizens about source sorting as this research showed that there is poor attitude to solid waste handling at source in the metropolis.

This study showed that there is no policy on generating energy from solid waste in the metropolis. It therefore becomes imperative for the formulation of relevant policies favourable for the use of solid waste for useful energy production. This will ensure sustainability of municipal solid waste management in Benin metropolis 


\section{REFERENCES}

EPA, Ireland, (1996): Municipal Waste Characterisation European Commission (2004): Methodology for the Analysis of Solid Waste (SWA-tool), 5th Framework Program, Vienna, Austria.

Federal Republic of Nigeria (FRN) (1999): 1999 constitution of the federal Republic of Nigeria

Igbinomwanhia, D.I., and Ohwovoriole, E. N. (2012), A Study of the Constraints to Residential Solid Waste Management in Benin Metropolis, Nigeria. Journal of Emerging Trends in Engineering and Applied Sciences (JETEAS) 3 (1): 103-107 (C) Scholarlink Research Institute Journals, 2012 (ISSN: 2141-7016). Online @ jeteas.scholarlinkresearch.org Indexed by Google Scholar

Moldan, B., Billharz, S. and Matravers, R. (eds) (1997). Sustainability Indicators: A Report on the Project on Indicators of Sustainable Development, John Wiley and Sons, Ltd, Chichester, p. 415
National Bureau of Statistics (2012): Annual Abstract of Statistics, 2012 Federal Republic of Nigeria online@ www.nigerianstat.gov.ng,

National Population Commission (2007): 2006 Population Census Final Figure. Federal Republic of Nigeria Official gazette, No. $25 \mathrm{Vol}$ 81

Rand, T., Haukohl, J. and Marxen, U. (2000): Inceneration of Solid Waste : A Decision Makers Guide, World bank, Washington DC

U.S. Environmental Protection Agency ( 2006) : Municipal Solid Waste in the United States, 2005 Facts and Figures online @ www.epa.gov

U.S. Environmental Protection Agency (2015) MSW Characterization Methodology. online @ www.epa.gov/sites/production/files/201509/documents/06numbers.pdf

WCED (1987) Our Common Future. World Commission on Environment and Development. Oxford University Press, Oxford. 